\title{
The Digital Linguistics: The Birth of Linguistic Humans 66,000 Years Ago in South Africa with Laryngeal Descent
}

\author{
Kumon Tokumaru \\ Digital Linguist, Japan \\ *Corresponding Author: tokumaru@pp.iij4u.or.jp; kalahari145ma@y-mobile.ne.jp \\ Received February 20, 2020; Revised April 20, 2020; Accepted April 27, 2020
}

Copyright $\bigcirc 2020$ by authors, all rights reserved. Authors agree that this article remains permanently open access under the terms of the Creative Commons Attribution License 4.0 International License

\begin{abstract}
Modern humans are linguistic humans, who acquired the logical properties of phonemes and morae in speech sound to generate an infinite number of word signs and to compose grammatically modulated sentences with complex meanings. 5KA (thousand years ago) they invented characters, which could display individual knowledge and intelligence to be shared and passed on to the following generations. Civilization itself is the linguistic phenomenon where knowledge and thoughts are transferred to subsequent generations via written documents, and very rapid consecutive innovations take place. In the 21st century, we are at the third and final stage of logical linguistic evolution with the interactive search and electric transfer of information via computer networks. It is necessary to clarify the in-brain mechanism for linguistic processing and intelligence to take full advantage of the final stage. The author outlines on the general overview of Digital Linguistics (DL) and identifies the birth of linguistic humans at the time of the laryngeal descent, which provided vowel accented syllables containing logical properties of phonemes and morae, to 66KA on the southern coastline of South Africa at the beginning of Howiesons Poort industry.
\end{abstract}

Keywords Linguistic Humans, Civilization, Howiesons Poort Neolithic Industry, Middle Stone Age (MSA) in South Africa, Inside Ventricle System Immune Networks, Mobile Neuron B Lymphocyte, Collective Human Intelligence

\section{Introduction - Three Stages of Digital Evolution of Linguistic Humans}

Digital Linguistics (DL) identifies that the modern human evolutions are linguistic; not only unconscious grammatical modulation and demodulation, but also rapid technological innovations in civilization can be explained as linguistic phenomena. There are three stages in such speech sound evolutions.

\subsection{Stage-I Laryngeal Descent to Vocalize Vowel Accented Syllables: Moraic Phonemes}

1) The Birth of Linguistic Humans with Logical Properties of Phoneme and Mora

Digital Linguistics stipulates that linguistic humans were born with the acquisition of logical properties in speech sound, namely phoneme and mora.

Phonemes are phonological elements that are distinctive in frequency in the speech sounds of a language, which can give rise to as many unique word signs as necessary by permutation.

Morae are rhythms or beats given by vowel accents. Individual sound waveforms of vowels provide beats and make syllables distinctive in the speech sound stream. Thanks to mora, grammatical syllables were invented as monosyllabic joints to indicate semantic modulation and connectivity of adjacent conceptual signs.

The critical evolution in human anatomy was the laryngeal descent, which followed the development of the mandibular bone. (Deagling 2012) The objective of this paper is to provide a comprehensive hypothesis on the place, timing and evolution process of laryngeal descent.

2) An Interdisciplinary Integration of Interdisciplinary Study, "Vowel", made by Chiba and Kajiyama

DL learned the importance of the mandible for the production of vowels in a classical work of phonetics which was published in Tokyo, The Vowel: Its Nature and Structure by Tsutomu Chiba and Masato Kajiyama (Chiba 
Kajiyama 1942) This monograph "opened the way to calculate a vowel spectrum from the data of the three-dimensional vocal tract shape for the first time in the history of phonetics." (Maekawa 2002)

Tsutomu Chiba (1883-1959) studied English literature at Tokyo Imperial University. From 1913 to 1916, the Japanese government sent him to England to study English philology. During this period, Chiba also learned phonetics probably by attending the lectures of Professor Daniel Jones at the University of London. After his return, Chiba taught phonetics at the Tokyo School of Foreign Language (TSFL) where he became a professor in 1919.

In 1928, TSFL received governmental funding for the improvement of its activities and decided to invest it in establishing Japan's first phonetics laboratory. The laboratory was established in 1929, and Chiba was nominated as its director. The laboratory was equipped with an anechoic chamber, X-ray apparatus, condenser microphones, and an electromagnetic oscillograph in addition to traditional devices like a kymograph and Helmholtz resonators.

Chiba's contribution to the laboratory was twofold: for one, it was his steady policy to introduce natural science, namely physics, into the study of phonetics, and for this purpose he continuously employed young physicists to help him. The interdisciplinary nature of the TSFL laboratory was in advance of the standard practice in the world at that time. For another, Chiba concentrated the laboratory's activity towards the study of vowels. Judging from his writings other than The Vowel, Chiba's main research interest was in the cross-language comparison of vowels, especially between Japanese and English. His experience of teaching English phonetics, however, led him to cast doubt on the scientific validity of the vowel diagram and the notion of the highest point of the tongue being the classificatory criterion of vowels.

Masato Kajiyama (1909-1995) was a physicist educated at Tokyo Imperial University. After spending one year as an assistant in the physics department where he was educated, he joined the phonetics laboratory of TSFL in 1933. His first work in the laboratory was the comparative analysis of accent in various languages, which was published as Chiba's monograph (Chiba 1935). (See 3.1)

Kajiyama then started his endeavors to reach a full understanding of the nature of vowels and continued in this direction until the publication of The Vowel. His contribution to The Vowel was both clear and enormous. He was the only physicist in the laboratory after 1933. Moreover, we have direct evidence of his contribution: the five volumes of laboratory notebooks that Kajiyama wrote during the years 1933-1940, which were preserved by Koh-ichi Kajiyama, Masato's son, and found in 2001 due to the present author's research. Figure 1 is a picture of a page from one notebook in which Kajiyama examined the distribution of particle velocity and sound pressure in a uniform pipe closed at one end. 


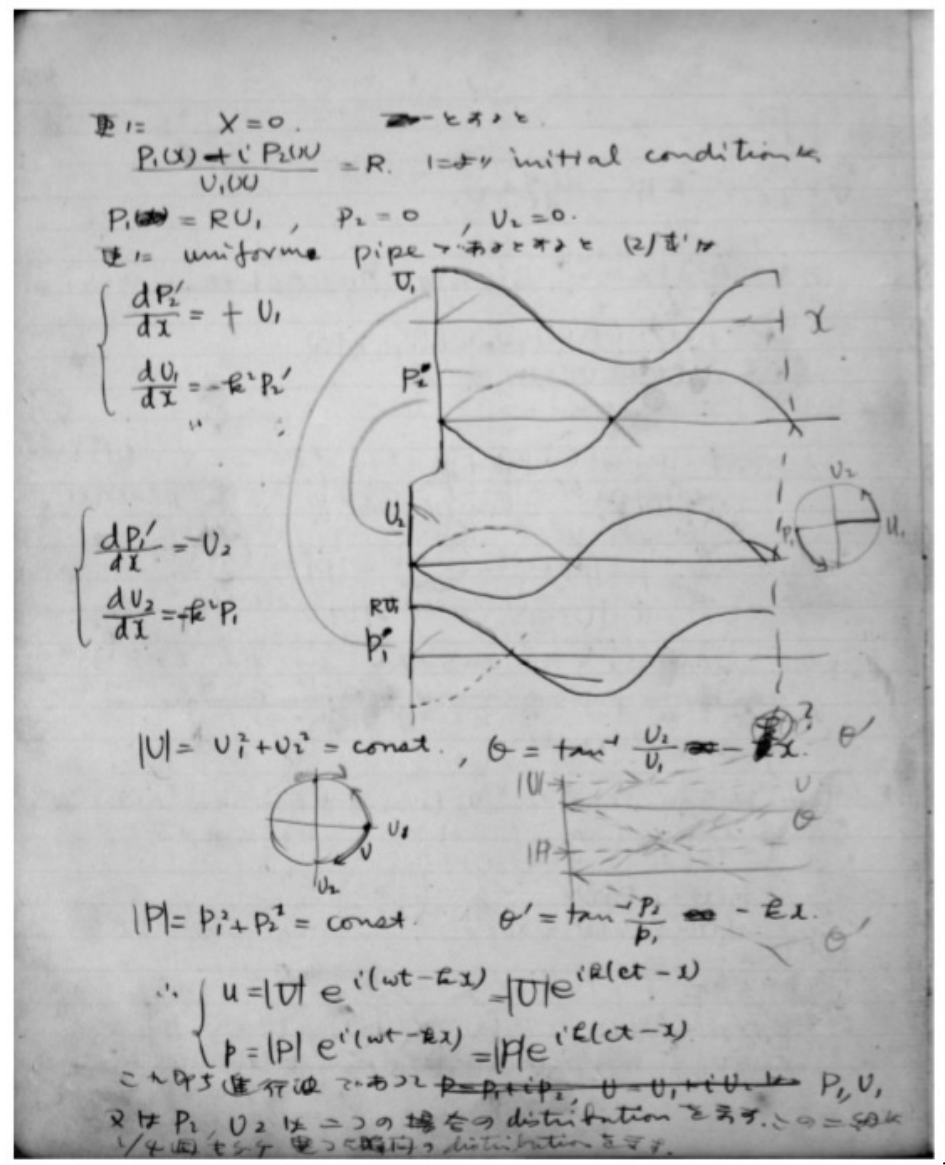

Figure 1. Kajiyama's laboratory note (Maekawa 2002)

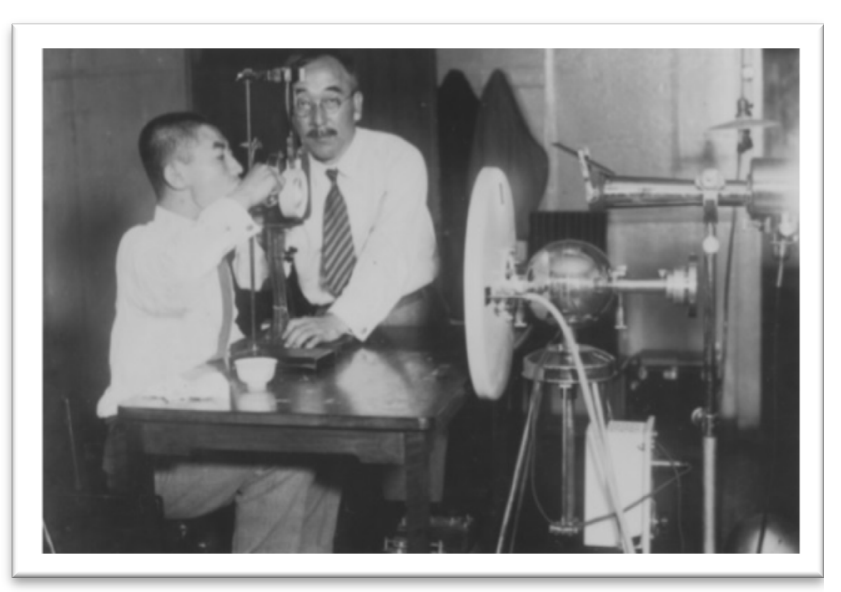

Figure 2. Chiba (right) and Kajiyama (left) in TSFL laboratory

In 1944, TSFL moved to a locality in northern Tokyo to evacuate from U.S. strategic bombing. But the new locality was not safe at all. Due to the incendiary bombing in the spring of 1945, the phonetics laboratory together with all experimental materials collected since 1929 was destroyed and lost forever. As far as I know, the only remaining material from the laboratory is a copy of an X-ray photograph and some photographs belonging to Kajiyama, which were reserved with the laboratory notebooks mentioned above. Figure 2 is a snapshot of Kajiyama (left) and Chiba (right) operating their stroboscope in the summer of 1933. (Maekawa 2002)

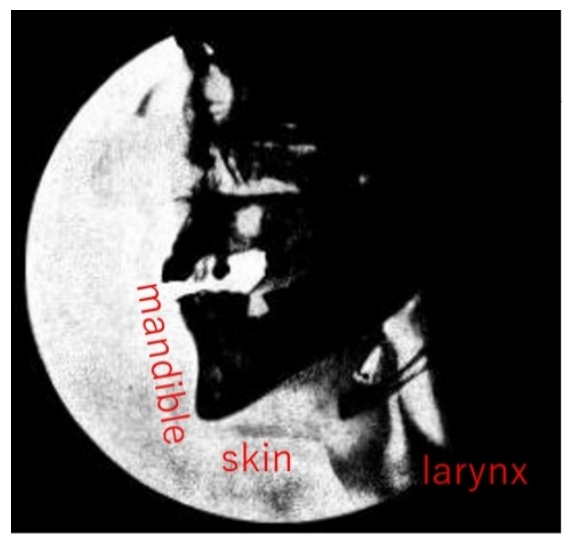

Figure 3. The developed mandible provided an open space under the oral floor which enabled the laryngeal descent to house vowel producing vocal tract. (Chiba Kajiyama 1942) 


\section{Doubly Concatenated Resonant Tubes}

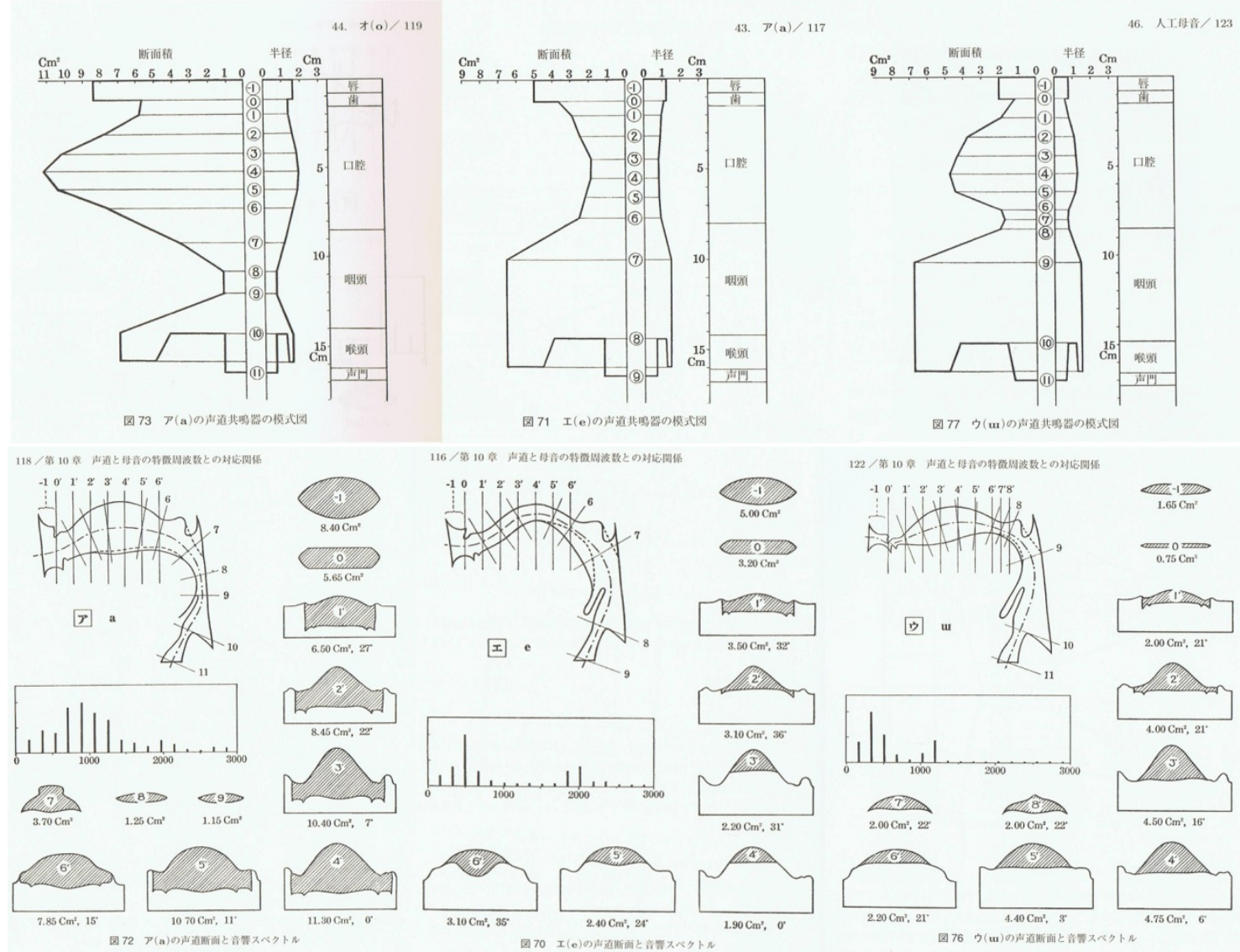

Figure 4. Three Dimensional Analysis of Vocal Tract (Chiba Kajiyama 1942)

Table 1. Three Stage Evolution of Human Language which started 66KA with the developed mandible, laryngeal descent and vowel producing vocal tract (A tabular reference model)

\begin{tabular}{|c|c|c|c|c|}
\hline 530MA & $3 \mathrm{MA}$ & $66 \mathrm{KA}$ & $5 \mathrm{KA}$ & $21^{\text {st }}$ Century \\
\hline \multirow[t]{4}{*}{$\begin{array}{l}\text { Vertebrates were } \\
\text { born with the } \\
\text { Ventricle System }\end{array}$} & \multirow[t]{4}{*}{$\begin{array}{l}\text { Early humans with } \\
\text { erect-bipedal and } \\
\text { opposable thumb } \\
\text { were born. }\end{array}$} & \multirow{3}{*}{$\begin{array}{l}\text { Modern humans } \\
\text { were born with } \\
\text { the developed } \\
\text { mandible and } \\
\text { laryngeal descent } \\
\text { to vocalize vowel } \\
\text { accented syllables. }\end{array}$} & \multirow{2}{*}{$\begin{array}{l}\text { Character sets are } \\
\text { syllables surviving } \\
\text { beyond time and } \\
\text { space, which } \\
\text { were born at } \\
\text { Intercontinental } \\
\text { huge plain or river } \\
\text { delta. }\end{array}$} & $\begin{array}{l}\text { Linguistic data } \\
\text { became } \\
\text { interactive and } \\
\text { searchable. }\end{array}$ \\
\hline & & & & \multirow{3}{*}{$\begin{array}{l}\text { 1) Interdisciplinary } \\
\text { integration of } \\
\text { sciences, 2 } \\
\text { Forward Error } \\
\text { Correction at } \\
\text { channel \& source } \\
\text { (3) Collective } \\
\text { intellect'l genome }\end{array}$} \\
\hline & & & \multirow{2}{*}{$\begin{array}{l}\text { Civilization, } \\
\text { Scientific } \\
\text { concepts }\end{array}$} & \\
\hline & & $\begin{array}{l}\text { Infinite words, } \\
\text { grammar, culture }\end{array}$ & & \\
\hline $\begin{array}{l}\text { Sign reflex } \\
\text { mechanism } \\
\text { consisting of } \\
\text { immune cell } \\
\text { networks (BSRF, } \\
\text { B lymphocytes } \\
\text { and Microglia) }\end{array}$ & & $\begin{array}{l}\text { At the expense of } \\
\text { sound localization } \\
\text { function at BSAN } \\
\text { to automatically } \\
\text { process sound } \\
\text { vector of } \\
\text { grammatical } \\
\text { syllables. }\end{array}$ & $\begin{array}{l}\text { Sign logic of If A } \\
\text { then B evolved } \\
\text { into Group theory } \\
\text { logic, and word } \\
\text { signs became } \\
\text { concepts. }\end{array}$ & $\begin{array}{l}\text { FEC to treat mass } \\
\text { data with } \\
\text { uncertain } \\
\text { reliability. To go } \\
\text { beyond } \\
\text { restrictions of } \\
\text { sign reflexes. }\end{array}$ \\
\hline
\end{tabular}


The author learned that, in South African archaeology, fossils of anatomically modern human with developed mandible were unearthed at the oldest modern human site, Klasies River Mouth Cave-1, and that, in Chiba-Kajiyama 1942, the developed mandible provided an open space between the oral floor and skin, where vowel producing vocal tract can be housed. At the starting point of DL, there was an interdisciplinary integration of interdisciplinary studies. A brief overview of DL is shown in Table-1. Tabular or schematic reference models are helpful to understand broad and complex interdisciplinary studies.

\subsection{Stage-II Civilization and Scientific Concepts}

\section{1) Literacy to Access External Extended Memory System}

Linguistic humans spent more than sixty thousand years without any external recording system for speech following laryngeal descent and the use of syllables. The second stage of evolution was the invention of a character set and literacy at Fertile Ccrescent in Mesopotamia $5 \mathrm{Ka}$. Literacy is the ability to translate written text into the sound of speech to be processed inside one's brain. Orthography defines the correspondence between speech sound and writing. In fact, literacy is the memorization of orthography. A literate person can hear the voice speaking from character strings and speak using a pen or keyboard. With literacy, the brain mechanism of linguistic humans is equipped with an extended external memory system, such as libraries, bookshops, the World Wide Web, etc. These contain lessons from around the world, translated international literature, scientific papers etc. A literate person can access any book or document, and easily assimilate the necessary information into the brain.

At the end of their biological life, literate humans can write their accumulated knowledge with a character set, so that subsequent generations can share their thoughts and experiences. This linguistic phenomenon enabled rapid and serial innovations which we call Civilization.

\section{2) Civilization}

Civilization started around $5 \mathrm{Ka}$ in vast river valley regions such as the Tigris-Euphrates, Nile, Indus-Ghanga and Yellow River. (Figure-5) To date, it has been universally assumed that such civilizations invented character sets. However, it was opposite: the invention of character set gave birth to civilizations, by enabling the sharing and handing down of knowledge. Although the life of individual biological human is limited to around 100 years, thanks to documentation and the dissemination of knowledge through reading, linguistic humans acquired logical immortality: this is the accumulation of knowledge over the generations. In this way, civilization transformed a dugout into a luxury ocean liner and a fire to signal into electric mail. This critical function of a writing system in rapid technological innovations has not been fully investigated.

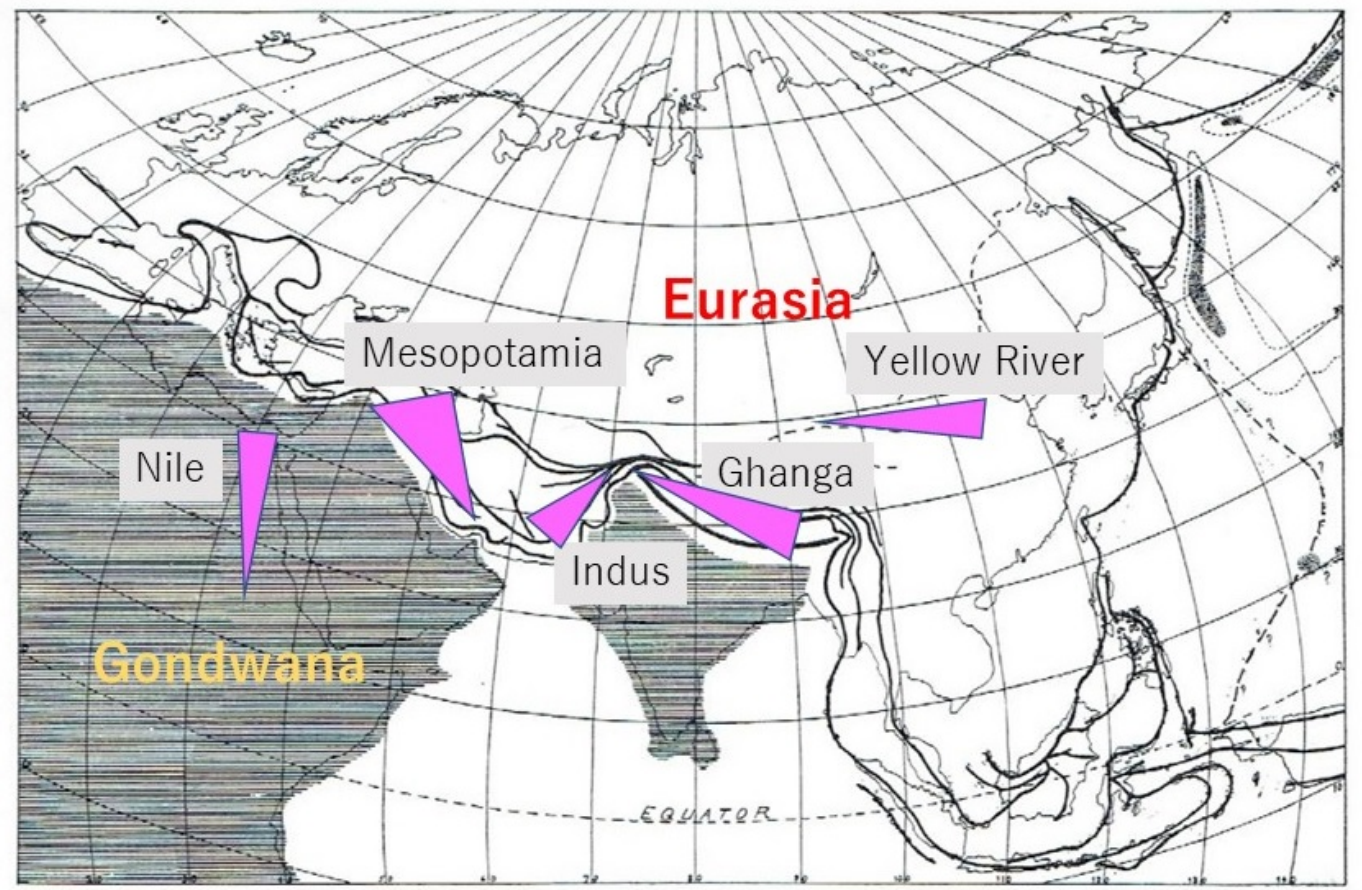

Figure 5. Civilization started at very flat and huge sedimental plain in continental gaps (Mesopotamia, Indus-Ghanga) and continental valleys (Nile, Yellow River), which necessitated writing system for taxation and administration. The author annotated a map featuring continental collision. (Taylor 1910) 


\section{3) Scientific Concepts}

In our daily life, most concepts are spontaneous and related to our individual and often accidental memories of experience, consisting of meanings of spontaneous concepts. Vygotsky (1935) differentiated scientific and daily spontaneous concepts. As far as the author knows, Vygotsky is the only psychologist who has focused on scientific concepts, and there has been little attempt by linguists to analyze them. Vygotsky's discussion on concept is general, and applicable to not only spontaneous but also scientific concepts. "(A) concept is more than the sum of certain associative bonds formed by memory, more than a mere mental habit; it is a complex and genuine act of thought that cannot be taught by drilling, but can be accomplished only when the child's mental development itself has reached the requisite level. At any age, a concept embodied in a word represents an act of generalization."

What follows is more of a non-spontaneous scientific concept or true concept, which starts to construct its meaning by dualistic operations after birth. “... word meanings evolve. When a new word has been learned by the child, its development is barely starting; the word at first is a generalization of the most primitive type; as the child's intellect develops, it is replaced by generalizations of a higher and higher type --- a process that leads in the end to the formation of true concepts. The development of concepts, or word meanings, presupposes the development of many intellectual functions: deliberate attention, logical memory, abstraction, the ability to compare and to differentiate. These complex psychological processes cannot be mastered through the initial learning alone." (Vygotsky "Thought and Language", MIT Press, 1986, p149-150)

The mechanism of meaning of scientific concepts are not related to sensory memories, but to the memories of dualistic thought operations. Therefore, at first, a thought (=conceptual) device without any meaning must mature, and we have to think a hundred or thousand times until its meaning is formulated, matured and stablized as a network of dualistic thought (=conceptual) operation memories. (Tokumaru 2019)

Scientific concepts and religious words are two sides of the same coin. It was Catholic monks in monasteries who tried to clarify the works of God in their silent life of work and study. Hence, they discovered the invisible laws of nature which had not been recognized or perceived by anybody before them: for example Copernican theory and Mendel's Law were discovered in this way. While religious words are rather subjective and superstitious, scientific concepts are objective and universal, which are constructed as networks of dualistic thought operation memories. Copernican theory and Mendel's Law were named after the scientists who first proposed them, and later were labelled as heliocentric theory and genetics, respectively.

In linguistics, we have not yet defined the in-brain mechanism for linguistic processing, the generation of new word memories and automatic grammatical modulation/demodulation. We mankind still live in a religious world as Chomsky exquisitely used a phrase "divine intervention": This (Martian) observer might also be amazed at the ability of every human child to acquire language, something that seems to him incomprehensible, requiring divine intervention, because the elements of the language faculty lie beyond his conceptual range. (Chomsky, "Language and Problems of Knowledge - The Managua Lectures", the MIT Press, 1988, p152.) DL envisages a set of theories and laws to transform linguistics into an empirical science. (Tokumaru 2018) (Tokumaru 2019)

\subsection{Stage-III: Computer Networks for Interactive Keyword Search and Instant Download}

Maynard Smith (1999) predicted, "The last transition, through which we are living today, is the use of electric means for storing and transmitting information. We think that the effects of this will be as profound as were those after the origin of the genetic code, or of language."

In the 21 st century, much linguistic information from the classical to the contemporary world is available in electronic form. If we put any keyword into a search engine, we can have a list of relevant linguistic information within seconds, which can be immediately accessed or downloaded. The Open Public Access Catalog (OPAC) of libraries indicates which libraries (even down to the exact shelf location) possess the books we need, and we can easily find new and/or secondhand books on the web, and pay online with a credit card. A lot of books, scientific papers and useful linguistic information can be downloaded as PDF or text files free of charge. We can access them via our smartphone or laptops from anywhere in the world.

With the help of keyword searches on computer networks, we are able to find relevant precedent work in the literature. Now the bottleneck becomes our reading and learning capability. It is time to enhance our brain capacity, by understanding its molecular-biological mechanism, to learn more, to think more and to advance collective human intelligence. If we can establish a self-study method using say a smart-phone device, a child who lives in rural Africa may be able to read by himself all that is relevant, expand these studies and become a Nobel prize winner. All the linguistic information since the dawn of history become meaningful with implementation of Forward Error Corrections, digital techniques to correct errors without contacting original authors. Collective human intelligence should be envisaged, shared and improved. These are some of the ultimate goals of DL.

\section{An Overview of Theoretical Development of Digital Linguistics}

DL is a new deployment of linguistics envisaging an 
interdisciplinary integration to identify the origin of modern human language as well as the in-brain linguistic processing mechanisms for daily concepts, scientific concepts (or complex logical concepts), and grammar. The study started in 2007, when the author, the first to make a study, visited the oldest modern human site, the Klasies River Mouth Caves (KRM) in the Eastern Cape Province of South Africa for the first time without the knowledge of digital nature of human language.

The archaeological excavation in 1967-68 (Singer Wymer, 1982) confirmed that (anatomically) modern humans had lived inside the caves during the period 120 $60 \mathrm{Ka}$ (Ka: thousand years ago). Royer et al. (2009) stated that '(T)his study demonstrates that size variation in the Klasies River mandibular and dental samples is greater than in modern human populations, supporting the hypothesis that this Middle Stone Age (MSA) population was more dimorphic.' This dimorphism indicates that the evolution of the mandibular bone should have taken place in KRM to house a descended larynx for vowel resonance.

The ideas of human language came from comparisons between modern humans and the Naked-Mole Rat (NMR, Heterocephalus glaber) who live in underground tunnels in the tropical savanna of East Africa. Like humans they are also naked with thin skin and thin hair; highly vocal and known for their eusocially structured and altruistic society. But NMRs have just 17 vocal signs in total. (Pepper Braude Lacey Sherman 1991) This significant difference in vocabulary between modern human and NMR can be explained by the fact that NMRs repeatedly vocalize the same analog sound patterns, whilst the human voice consists of ever changing conceptual and grammatical syllables to transmit sentences and paragraphs. Human language has a vocabulary of more than 100,000 words and can generate as many new word signs as are necessary by permutation of phonemic syllables. Then the author got an inspiration that human language is digital.

Maynard Smith (1999) concluded in "the origins of life": The analogy between the genetic code and human language is remarkable. ... in both systems a linear sequence of a small number of kinds of unit can specify an indefinitely large number of outcomes. ... the discrete, digital nature of the units is probably necessary...It would be interesting to know how far these languages are digital.

Using an internet search engine with "human, digital, language" as keywords, the author discovered a synthesis paper written by a molecular biologist (Noll 2003), which introduced the provocative idea of Niels K. Jerne (1974, 1984) on the immune network mechanism as meaning mechanism and B lymphocyte as a conceptual device. These two lectures of Jerne provided DL with the basis to hypothesize the Inside Ventricle System Immune Networks for the Mechanism of Meaning.

DL identifies phonemes and morae as fundamental logical elements in language to analyze the person-to-person physical layer transmission and the in-brain logical layer linguistic processing. In the three stages in the evolution of physical layer speech sound stream as described in section 1, phonemes and morae are critical. Stage I started with the acquisition of vowel accented syllables containing phonemes and morae, and Stage II/III are based on the interchangeability between character strings and syllables, moraic phonemes.

\section{Phonemes \& Digital Permutation}

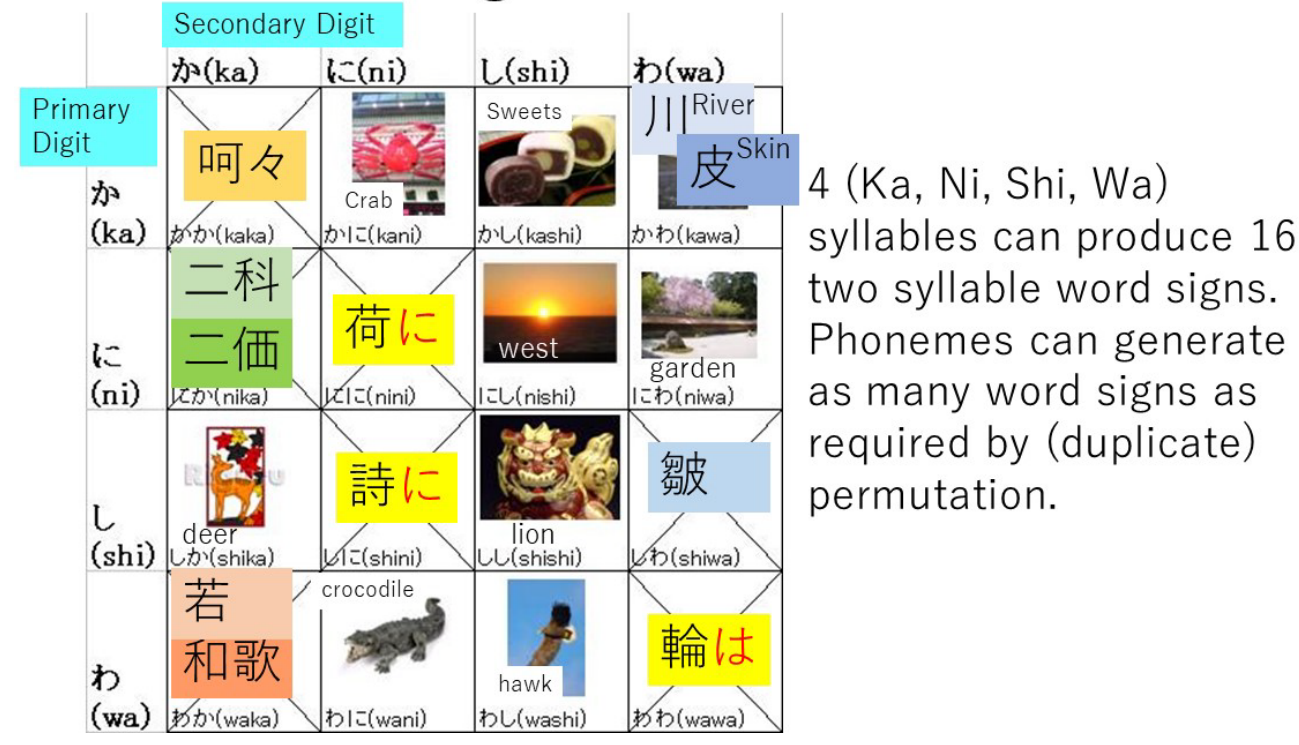

Figure 6. Example of Japanese syllables 


\section{Breakthroughs in Speech and a Bricolage in Brain Mechanism}

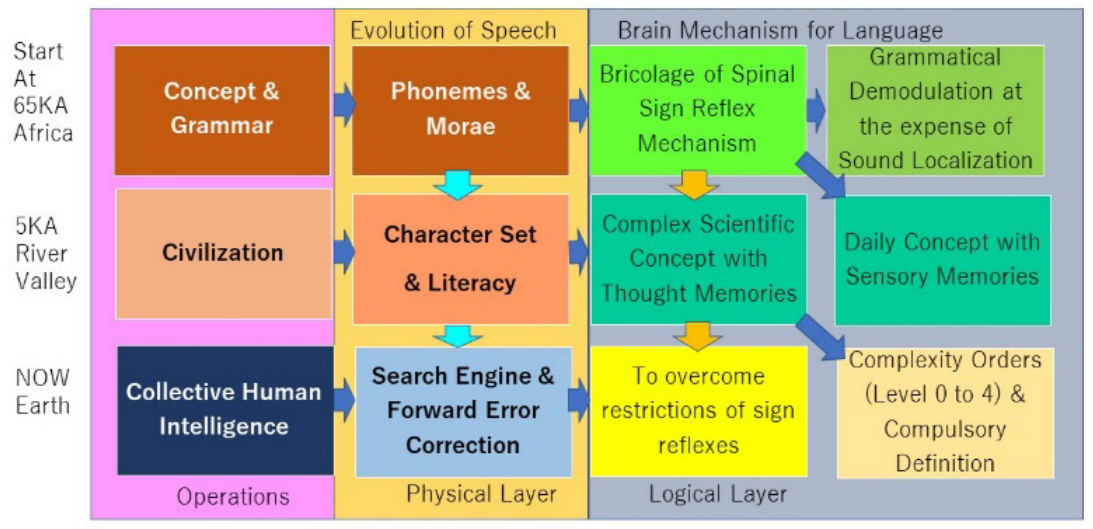

Figure 7. 3 Breakthroughs in Speech Sound (Phy. Layer) and a Bricolage in Brain Mechanism (Log. Layer)

Anatomically there is no unique brain mechanism or organ for modern humans such as a Language Acquisition Device or Linguistic Brain for linguistic processing. There is no cellular or molecular level hypothesis to explain the so-called Broca and Wernicke areas on the neocortex functioning as a linguistic center. It is highly probable that we use the spinal sign reflex mechanism as bricolage: the linguistic processing and intelligence are antigen-antibody Neuro-Immune cell networks inside the cerebrospinal fluid in the Ventricle System. This is a Tokumaru theory obtained from two Jerne lectures and interdisciplinary research. It is necessary to hypothesize the transduction mechanism of syllabic sound waveforms into in-brain molecular structures.

In the 21 st century, we are expected to take full advantage of computer networks and complete the evolution of linguistic humans by (i) establishing a collective human intelligence with the correction of errors made by our predecessors, (ii) overcoming various restrictions of spinal sign reflexes as an intellectual system: (a) memory based reflexive response mechanism, which tends to neglect or overlook unknown word signs, (b) ego-centric mechanism, which tends to determine right or wrong based on previously acquired individual knowledge, (c) self-protective and self-sufficient mechanism, which decreases intellectual curiosity at very early stage of life, etc., (iii) improving literacy so that more people are able to access literature via the World Wide Web and (iv) enhancing our learning and thinking sign reflex mechanism by stimulating our immune system.

\section{Transduction Mechanism of Syllabic Sound Waveforms into in-brain Molecular Structures}

\subsection{Amplitude Envelope Fluctuations of Word Sign Waveform}

Here, the author tentatively defines phonemes as (i) a set of speech sound elements in one language distinctive in frequency domain, and (ii) capable of generating as many word signs as are necessary by their permutation. As concepts are located at the heart of linguistic communications and thought operations, phonemes play a key role to differentiate a concept from the others.

Phillips (2001), who is reluctant to admit that the cortex is involved in speech sound processing, states that "the representation in the cortex of speech sounds is acoustic rather than phonetic, and is independent on voice pitch." And, "insofar as human speech sounds are concerned, it is unlikely that cortical neurons are able to entrain spikes to the glottal pulses that set the voice pitch, but there is no doubt that they can indicate the timing of the phonetically important components of the speech signal. In this regard, there is recent evidence that the most important temporal components of the speech signal are the slower, amplitude envelope fluctuations, rather than the waveform's fine time structure."

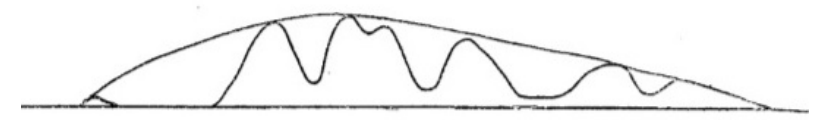

Figure 8. Amplitude peaks of syllables are linked to formulate a smooth curve. The above represents “jusqu'à la révolution”. (Chiba 1935)

The comparison between the slower amplitude envelope fluctuations and the waveform's fine time structure is visualized by Chiba (1935, Figure-8). Although this work was published as Chiba's monograph, Kajiyama's name was mentioned in the preface. (Maekawa 2002) After having measured the fine time structure of frequency and amplitude, Chiba outlined the envelope. It seems that the envelope derives from multiplexed waveforms of amplitude and frequency, and thus represents an energy curve. It is plausible that the 3-D structure of antigens should represent such an envelope shapes. A critical function of an amplitude envelope was confirmed when I said the word "Pakistan", then Ms. Takeshita reacted as she felt that she had heard her name being called. The 
similarity between Pakistan and Takeshita (pronounced with Japanese flat intonation) should be in the envelope shape.

DL supposes that the ambient speech sound is represented by the antigen molecular structure inside the brain Ventricle System (VS). (Tokumaru 2018) Table-2 is the result of Network Requirement Analysis for inside VS Immune Cell Networks for the Word Sign Reflex. Antigen terminals of CSF-Contacting Neuron and Microglia represent "amplitude envelope fluctuations" of individual phonetic stimuli of words. Antibody of B lymphocyte constitutes a specificity pair with the antigen terminal. Word phonetic stimulator (= CSF-CN) and sensory memories related to that word (=Microglia) are mediated by the Concept Device (= freely moving B lymphocytes inside CSF) for daily spontaneous concepts. The meaning of scientific concepts is to be established as a network of dualistic thought operation among B lymphocytes inside the CSF. This is a brief overview on the meanings of daily and scientific concepts.

Table-2 shows that sensory memories stored in microglia are passive and to be recognized by $\mathrm{B}$ lymphocytes. For example, when we happen to see our old friend on the street, we recognize their face, but we cannot remember their name. This is because sensory memories are fixed in the neocortex and need to be recognized by mobile concept devices. It is plausible that antigen and antibody structures of a specificity pair representing amplitude envelopes of individual words are generated inside the ventricle system when we learn a new word. The learning is a process of neuroblast cells maturing with antigen and antibody terminals.

Table 2. Network Requirement Analysis for Word Sign Reflex

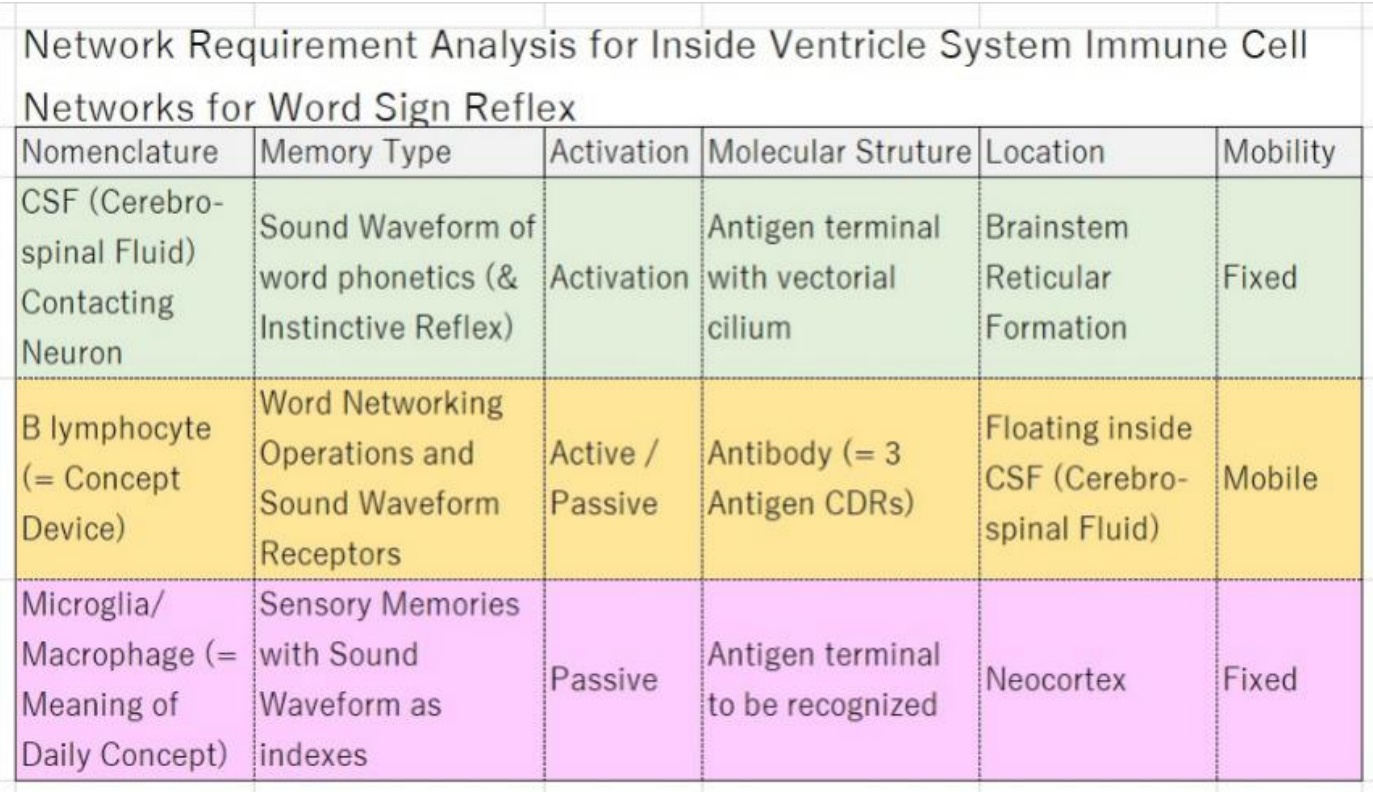




\subsection{Time Domain Distinctiveness to Allow Insertion of Grammatical Syllables to Be Analyzed as Sound Vectors in Monaural Audition}

Mora is logical because the rhythm or beat of vowel accents punctuates the speech sound stream into time slots, when listeners can predict the existence of a syllable in each time slot. Due to the logical properties of mora, each syllable contained in the speech sound stream becomes distinctive in time; and two different types of syllables, namely conceptual and grammatical, can be alternatively vocalized without any indication or mark.

It is interesting to note that some moraic (=syllabic) language such as French and Japanese have unique grammatical structures "langage articulé" $(\mathrm{g}+\mathrm{C})$ and "bunsetsu" $(\mathrm{C}+\mathrm{g})$, the minimum semantic units with a standardized order of a grammatical and conceptual syllables. They indicate that grammatical syllables modulate adjacent concepts.

The onomatopoiec feature of grammatical syllables indicates that they are analyzed as sound vectors. We hear our mother tongue monaurally and convert the sound localization function of the brainstem auditory nuclei for vector analysis of sound waveform of grammatical syllables. The author surmises that this monaural hearing of one's mother tongue and sound vector analysis at the Brainstem Auditory Nuclei is the answer to Chomsky's conundrum: Why humans can compose an appropriate new sentence in a particular situation, and, why, with hearing it only once, others can understand it immediately? (Chomsky 1964).

\section{Oku no Hosomichi C+g structure}

- (TSUKIHIwa)(HYAKUDAIno)(KAKAKUnishite)(YUKIKAU)(TOSHImo)(mata)(TA BIBITOnari)(FUNEno)(UEni)(SHOUGAIwo)(UKABE)(UMAno)(KUCHI)(TORAE te)(Olwo)(MUKAURU)(MONOha)(HIBI)(TABInishite)(TABIwo)(SUMIKAto)(S U)(KOJINmo)(OOKU)(TABIni)(SHISEru)(ARI)(Yomo)(IZUREno)(TOSHlyorika)( HENUNno)(KAZEni)(SASOWAREte)(HYOHAKUno)(OMOI)(YAMAZU)(KAIHINn i)(SASURAHE)(KOZOno)(AKI)(KOJOno)(HAOKUni)(KUMOno)(FURUSUWo)(H ARAlte)(yaya)(TOSHImo)(KURE)(HARU)(TATEru)(KASUMIno)(SORAni)(SHIR AKAWAno)(SEKI)(KOEnto)(SOZOROGAMIno)(MONOni)(TSUKIte)(KOKOROW o)(KURUWAse)(DOSOJINno)(MANEKIni)(Aite)(TORU)(MONO)(Teni)(TSUKA zu)(MOMOHIKIno)(YABUREWo)(TSUZURI)(KASAno)(O)(TSUKEKAEte)(SANRI ni)(KYU)(SURUyori)(MATSUSHIMAno)(TSUKI)(MAZU)(KOKOROni)(KAKARIte )(SUMERU)(KATAWa)(HITOni)(YUZURI)(SANPUga) (BESSHOni)(UTSURUni) (KUSAno)(TOMo)(SUMIKAWARU)(YOZO)(HINAno)(IE) (OMOTEHAKKUWo)(IORIno)(HASHIRAni)(KAKEOKU)

- No Subject/Pronoun/Article. Less Logical than French language.

Figure 9. Japanese Bunsetsu $\mathrm{C}+\mathrm{g}$ structure

\section{Descartes『Discourse on the Method』 " $\mathrm{g}+\mathrm{C}$ " Structure}

- 「Or」「par」「ces deux」「mêmes」「moyens」, 「on peut」

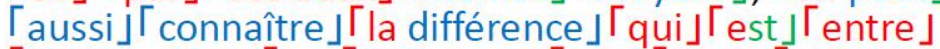

$\lceil$ les hommes $\rfloor$ et $\lceil$ les bêtes.」「Car」「c'est」「une chose $\lceil$ bien $\rfloor$ remarquable $\left\lceil\right.$ qu'il $\\left\lceil n^{\prime} y\right.$ a $\rfloor\lceil$ point $\rfloor$ $\left\lceil d^{\prime}\right.$ hommes」「si」「hébétés」「et」「si」「stupides」「sans en excepter $\lceil$ même」「les insensés」, 「qu'ils」「ne soient $\rfloor$ capables $\rfloor$ d'arranger $\rfloor$ ensemble $\rfloor$ diverses」 $\lceil$ paroles $\rfloor$ et $\rfloor\lceil$ d'en composer $\rfloor\lceil$ un discours $\rfloor\lceil$ par lequel」「ils fassent $\rfloor$ entendre」「leurs pensées $」\lceil$ et $」$

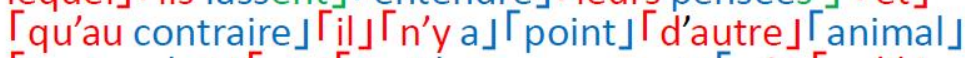
$\lceil$ tant parlait」「et $\rfloor\lceil$ tant heureusement $\rfloor\lceil$ né $\lceil$ qu'il」 $\lceil$ puisse」「être」「qui fasse $\lceil$ le semblable.」

French expressions are logical because they start with logical code (grammars) such as Pronouns, Conjunctives and Articles which require grammatical subordination with the following content words.

Figure 10. Frence langage articulé $\mathrm{g}+\mathrm{C}$ structure 
Westphal (1971) states that, in "some of the Khoisan languages, most content words begin with clicks, but very few function words do." Content words are concepts such as nouns, verbs and adjectives, and function words are grammatical. He indicated that clicks could not generate grammatical words, probably because they are not moraic. It is plausible that grammatical modulation started with the acquisition of morae with vowel accented syllables.

As grammatical modulation/demodulation is one of most important characteristics of human linguistic communication, the author proposes that the linguistic human emerged when the logical property of mora came about following the laryngeal descent. Mora is so critical in human digital linguistic communications.

\section{South African Single Origin Hypothesis for Linguistic Human Evolutions}

The Recent African Single Origin Hypothesis (RASOH) was first proposed by Cann, Stoneking and Wilson (1987), followed by supportive and more precise analysis (Henn 2011), and became the global standard in anthropology. However, archaeology and linguistics have not yet combined their hypotheses on the origins of modern humans into RASOH. The author proposes the RASOH for linguistic humans.

\subsection{Why Anthropology and Archaeology of South Africa Has Such a Low Profile?}

In 1924, the fossil of Taung Child was discovered in South Africa by Dr. Raymond Dart. The Klasies River Mouth Caves are the oldest modern human site. Although there is a tremendous number of early and modern human sites in South Africa, there has not been much research or discussion to incorporate South African anthropology and archaeology. It seems that researches into South African Stone Age have been isolated from international recognition due to both South African domestic policies and the international academic boycott from 1960s to 1990s.

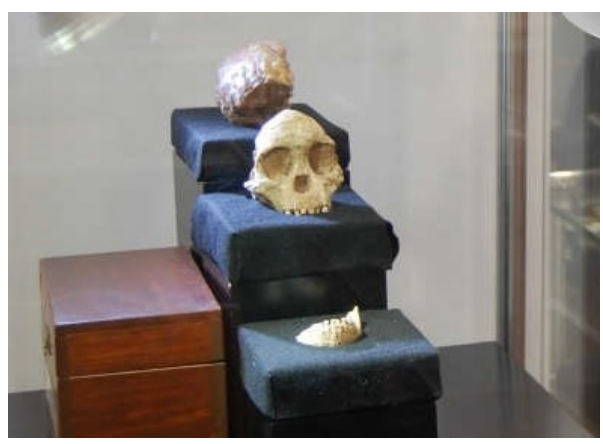

Figure 11. Taung Child (Original) with undeveloped mandible Institute of Evolutionary Studies, Witswatersrand University

\subsubsection{South African Archaeology almost Disappeared around $1960 \mathrm{~s}$}

Since the early 1960s, South African archaeology has been obscured. At the start of this period, two prominent and leading archaeologists, 'Peter' van Riet Lowe (1894-1957) and John Goodwin (1900-1959) both passed away. Their book "The Stone Age Cultures of South Africa" is the only book which provides an overview on South African archaeology from Early to Late Stone Age (Goodwin Lowe, 1929). Goodwin was the first South African national to study archaeology at Cambridge, and returned to work at the University of Cape Town. He founded the South African Archaeological Society (SAAS) and worked as the first editor of the South African Archaeological Bulletin (SAAB). Riet Lowe was the first Director of the South African Archaeological Survey, a governmental body. In 1962, the South African Archaeological Survey was dismantled and closed without explanation, and the second Pan African Congresses on Prehistory and Quarternary Studies to be hosted at Johannesburg was also cancelled.

Later members of the SAAS were offered jobs in the U.S.A. and left their homeland: in 1962, Ronald Singer (1924-2006), the president of SAAS and anatomist at the Univ. Cape Town Medical Faculty, became chairman of the University of Chicago's Department of Anatomy, and the next president, John Robinson (1923-2001), Director of Transvaal Museum, moved to the University of Wisconsin, Madison. Post-graduate students, Glynn Isaac (1937-1985) and Carmel Schrire (1941- ), went abroad.

In addition, early human fossils discovered in Tanzania by Louis Leakey (1903-1972), a former President of SAAS, and Mary Leakey (1913-1996) diverted international attention from South African archaeology.

\subsubsection{International Academic Boycott and its Effect}

On March 21st 1960 in Sharpeville, a black township to Vareeniging about $50 \mathrm{~km}$ south of Johannesburg, the South African police opened fire on a large group of locals who were gathering peacefully near the police station. Sixty nine people were killed including eight women and ten children, and one hundred and eighty were injured including thirty one women and nineteen children. On 30th March 1960, the government declared a state of emergency and banned both liberation movements African National Congress (ANC) and Pan Africanist Congress (PAC). In 1961, South Africa had left the Commonwealth of Nations. It seems that the South African government had set out to become internationally isolated.

In the six decades, "since it occurred, we have not had a truly comprehensive history of the massacre. The behavior and motivations of the police remain unclear, for example, and until recently the government discouraged investigations into any aspect of the affair." (Welch 2005)

Ambrose Reeves wrote in 1968 in a paper for the United Nations, "Early that morning (21 ${ }^{\text {st }}$ March 1960) a crowd of Africans estimated between 5,000 and 7,000 
marched through Sharpeville to the municipal offices at the entrance to the township. It appears that much earlier that day members of the Pan Africanist Congress had gone around Sharpeville waking up people and urging them to take part in this demonstration. ..... Eventually this demonstration was dispersed by the police, using tear gas bombs and then a baton charge, some sixty police following them into the side streets. Stones were flung and one policeman was slightly injured. It was alleged that several shots were fired by Africans and that only then some policemen opened fire without an order from their officer to do so. Fortunately nobody was hurt."

"At the hours passed the increasing number of people in the crowd was matched by police reinforcement. Earlier there had only been twelve policemen in the Police Station: six white and six non-white. But during the morning a series of reinforcements arrived until by lunchtime there was a force of nearly 300 armed and uniformed men in addition to five Saracens....."

"The only action taken during that morning appears to have come not from the police but from two Pan Africanist leaders who urged the crowd to stay away from the fence around the perimeter of the compound so that they did not damage it. ... "Lieutenant-colonel Piennar was quite clear that he wound not have fired in that situation. It was stated later that two white policemen opened fire and that about fifty others followed suit, using service revolvers, rifles and sten guns.

But whatever doubts there may be of the sequence of events in those fateful minutes, .there can be no argument over the devastating consequence of the action. ..... the massacre was horrible.." (Peart-Binns 1973)

His book which was immediately published after the massacre contains 30 photographs before/during/after the shooting taken by professional newspaper photographers and Appendix II: Extracts from evidence before the Court of Enquiry. (Reeves 1960) These photographs and court witnesses show no evidence of demonstration or protest at all on that morning in front of the Sharpeville Police Station. There are contradictions between Reeves (1960) and his paper for UN (1968), but why? Are these contradictions related to unknown origin of the international academic boycott against South Africa?

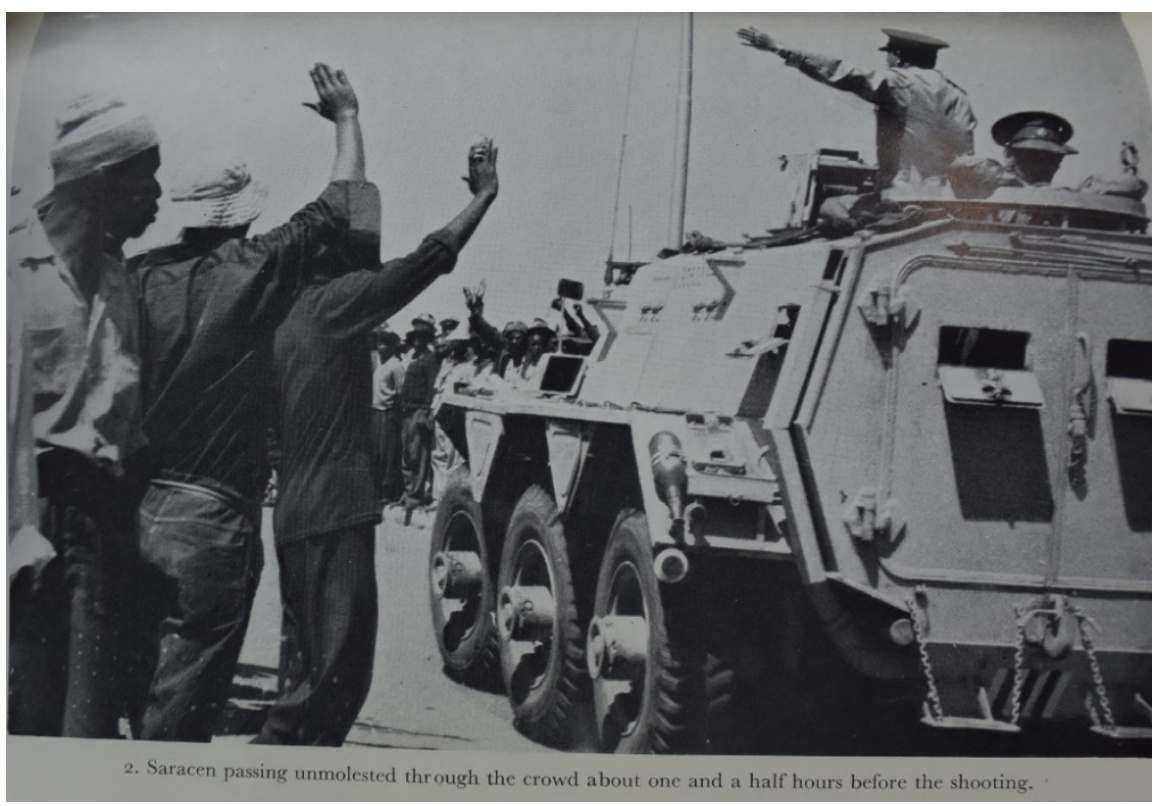

Figure 12. Saracen passing unmolested through the crowd about $11 / 2$ hours before the shooting 


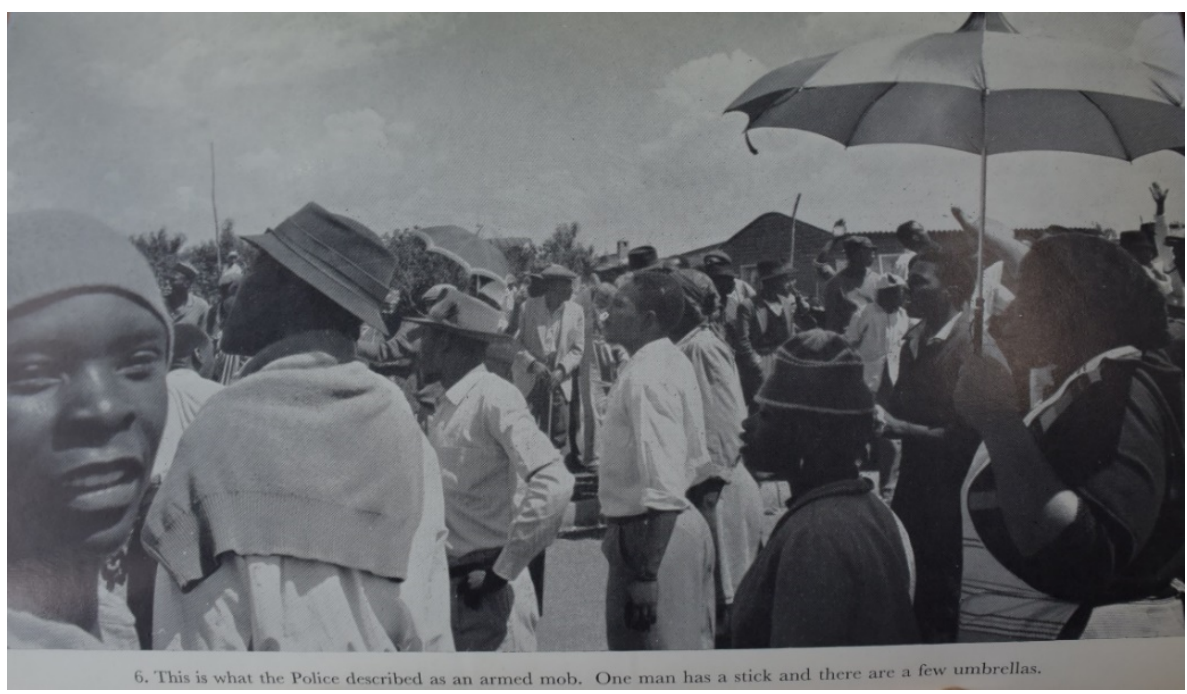

Figure 13. This is what the Police described as an armed mob. One man has a stick and there are a few umbrellas.

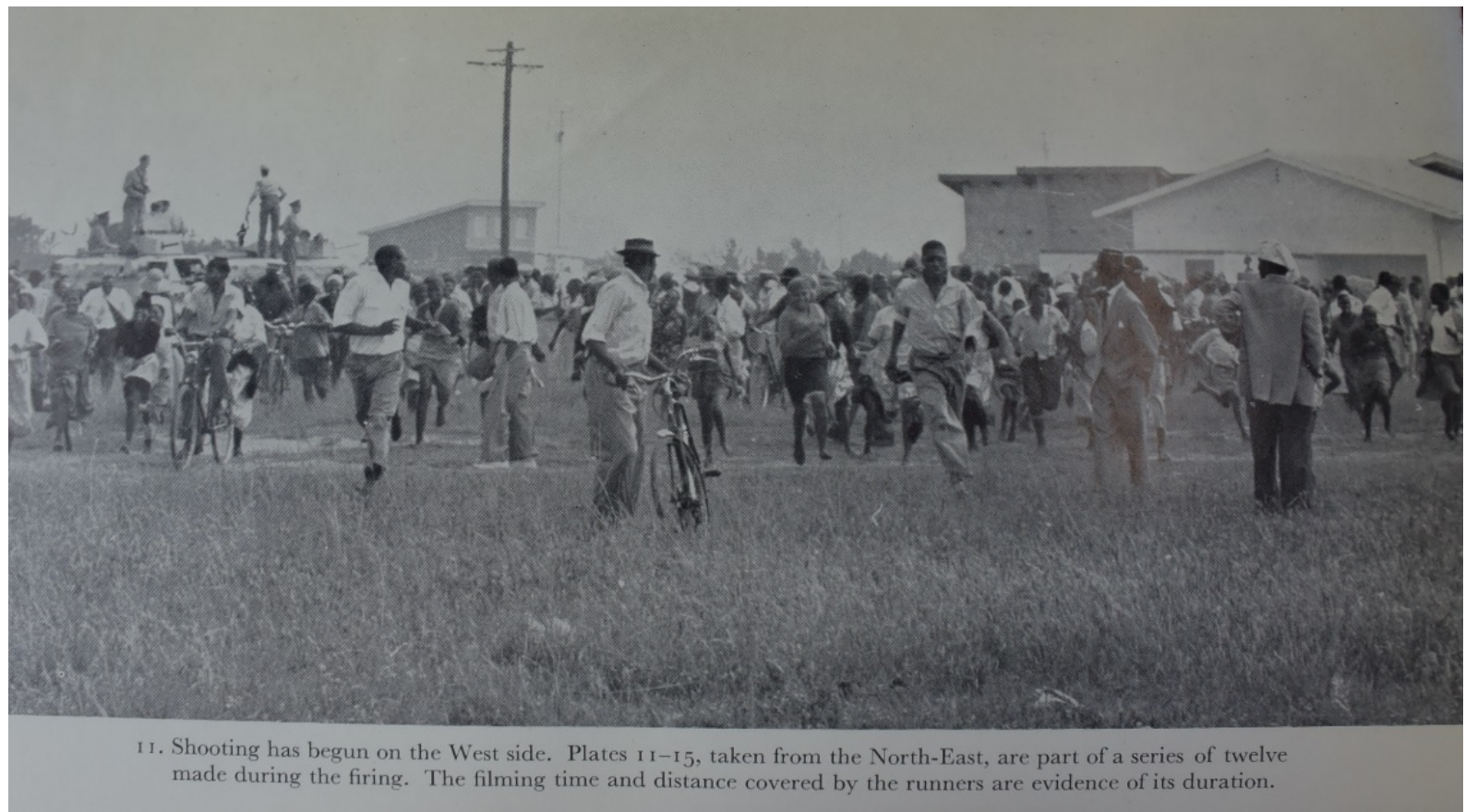

Figure 14. During the firing: Shooting has begun on the West side. None of those fleeing carries a weapon. 
It is not clear by whom, when and how the international academic boycott against South Africa started. There is no record in any international academic organization which called for the academic boycott against South Africa. The Anti Apartheid Movement (AAM) in Britain, which had started as the Boycott Movement in 1959, seemed to be one of the leading advocates for a boycott, and the boycott proved to be thorough, extensive and hysterical (Minty 2017). "Local left-wing pressure-groups" were very active when the British "national organizing committee" banned South Africans from the World Archaeological Congress held in Southampton, U.K. in 1986, without a thought of the importance of South African archaeology to the studies of early Hominids or the Modern Humans at all (Ucko 1987).

The academic boycott was a comprehensive isolation of both South African academics and journals. "At least eight manifestations of this boycott can be recognized: 1 . Scholars refusing to travel to South Africa or to invite South Africans abroad; 2. Publishers, journals, and the like, refusing to publish South African manuscripts; 3. Scholars abroad refusing to collaborate with South African scholars; 4. Publishers abroad refusing to provide access to information (for example, books or computer software); 5. International conferences barring South Africans; 6. Institutions abroad denying South African academics access; 7. Institutions abroad refusing to recognize South African degrees; 8. Scholars abroad refusing to act as external examiners for theses presented at South African universities." (Lancaster 1995) Unfortunately it was a double-edged sword particularly in the fields of archaeology and anthropology where rich and varied samples were available in South Africa. By boycotting South Africa, international archaeologists missed the chance to familiarize themselves with the place where early and linguistic humans emerged.

We cannot know what we do not know, and this effect has hardly been discussed or acknowledged. At the end of the apartheid era, international archaeologists still did not pay particular attention to looking over 30 years of intellectual isolation in South Africa, which has, even up to today, denied them the opportunities to study the richness and importance of South African archaeology. This could be the reason why Still Bay and Howiesons Poort have not yet been integrated into the hypotheses on the origin of linguistic humans. There are many archaeologists in the world who do not know the SB and HP industries, not to mention linguists.

The author participated in the annual conference of Anthropology Southern Africa (ASnA) in 2015, "ASNA
Conference: Ethnography and Worlds Otherwise", 30 August - 2 September 2015, North-West Univeristy, Potchefstroom, South Africa. The majority of the presentations were on social anthropology based on the personal histories of the speakers. There was not a single presentation on the evolution of early and modern humans by researchers from South Africa nor from other international participants except for myself. My presentation title was "Clicks and Vowels two stage evolution of human language at Still Bay and Howiesons Poort Technocomplexes".

\subsection{South Africa is the Most Probable Place of Human Evolutions: The Cradle of Humankind and the Origin Center}

The UNESCO World Cultural Heritage site of "The Cradle of Humankind" has a visitor center at Sterkfontein caves within one hour's drive from Johannesburg city center, where fossils of early humans have been discovered. The author believes it should be renamed as the Cradle of Early Humankind, because they did not use language. The artefacts belonging to Still Bay and Howiesons Poort technocomplexes in Middle Stone Age are displayed at the Origin Center, Witswatersrand University. The fact that in Johannesburg there are two big museums with locally unearthed fossils and artefacts of early and modern humans is significant. No other country in the world has such a wide selection of fossils and artefacts of human evolution as South Africa. It is envisaged that anthropological fossil records and archaeological artefacts should be included into the hypothesis of the emergence of linguistic humans.

\subsection{South African Middle Stone Age as the Backdrop to the Evolution of Linguistic Humans}

The South African Stone Age (Table-3) is divided into three periods: Early Stone Age (ESA, 2 MA - 200KA), Middle Stone Age (MSA, 300KA - 20KA) and Later Stone Age (LSA, 40KA - ). MSA started about 300KA probably with the use of fire for cooking. Hunter-gatherers foraged along the seashore for shells and fish, and probably cooked seafood over fire. As there are a lot of hollowed caves along this coastline, they started to use caves for their homes. Caves in the sea cliff some $20 \mathrm{~m}$ above sea level provided an extremely safe environment against enemies or predators. In such a safe environment, new born babies could stay in the crib for at least one year without having to fend for themselves; thus, modern humans started to deliver helpless infants. 
Table 3. South African Stone Age Sequences (Lombard et al 2012)

\begin{tabular}{|c|c|c|c|}
\hline Period & SAL technocomplex & Also known as (including regional variants) & $\begin{array}{l}\text { Broadly } \\
\text { associated MISs }\end{array}$ \\
\hline \multirow[t]{6}{*}{$\begin{array}{l}\text { Later Stone Age } \\
<40 \mathrm{ka}\end{array}$} & ceramic final Later Stone Age $<2 \mathrm{ka}$ & $\begin{array}{l}\text { ceramic post-classic Wilton, Late Holocene with pottery (Doornfontein, } \\
\text { Swartkop) }\end{array}$ & MIS 1 \\
\hline & final Later Stone Age $0.1-4 \mathrm{ka}$ & post-classic Wilton, Holocene microlithic (Smithfield, Kabeljous, Wilton) & MIS 1 \\
\hline & Wilton 4-8 ka & Holocene microlithic (Springbokoog) & MIS 1 \\
\hline & Oakhurst 7-12 ka & $\begin{array}{l}\text { Terminal Pleistocene/early Holocene non-microlithic (Albany, Lockshoek, } \\
\text { Kuruman) }\end{array}$ & MIS 1 \\
\hline & Robberg 12-18 ka & Late Pleistocene microlithic & MIS 2 \\
\hline & early Later Stone Age $18-40 \mathrm{ka}$ & (informal designation); Late Pleistocene microlithic & MIS 2 to MIS 3 \\
\hline \multirow{8}{*}{$\begin{array}{l}\text { Middle Stone Age } \\
>20 \text { to }<300 \mathrm{ka}\end{array}$} & final Middle Stone Age 20-40 ka & (informal designation) MSA IV at Klasies River, MSA 4 generally & MIS 2 to MIS 3 \\
\hline & Sibudu $45-58 \mathrm{ka}$ & $\begin{array}{l}\text { late MSA/post-Howieson's Poort or MSA III at Klasies and MSA } 3 \text { generally } \\
\text { (all informal designations) }\end{array}$ & MIS 3 \\
\hline & Howieson's Poort 58-66 ka & & MIS 3 to MIS 4 \\
\hline & Still Bay $70-77 \mathrm{ka}$ & & MIS 4 to MIS $5 \mathrm{a}$ \\
\hline & pre-Still Bay 72-96 ka & (informal designation) & MIS 4 to MIS 5 \\
\hline & Mossel Bay 77-105 ka & MSA II at Klasies River, MSA 2b generally (Pietersburg, Orangian) & MIS $5 \mathrm{a}-\mathrm{c}$ \\
\hline & Klasies River $105-130 \mathrm{ka}$ & MSA I at Klasies River, MSA 2a generally (Pietersburg) & MIS 5d-e \\
\hline & early Middle Stone Age 130-300 ka & (informal designation) & MIS 6 to MIS 8 \\
\hline \multirow{3}{*}{$\begin{array}{l}\text { Earlier Stone Age } \\
>200 \mathrm{ka}\end{array}$} & ESA-MSA transition $>200-600 \mathrm{ka}$ & (informal designation) (Fauresmith, Sangoan) & MIS 7 to MIS 15 \\
\hline & Acheulean $300 \mathrm{ka}-1.5 \mathrm{Ma}$ & & MIS 8 to MIS 50 \\
\hline & Oldowan $1.5-2 \mathrm{Ma}$ & & MIS 50 to MIS 75 \\
\hline
\end{tabular}

Human babies are born in a helpless condition, which Portmann (1944) named "secondary altriciality", as primates are precocious. Martin (1990) explains that the big brain size of anatomically modern humans was achieved by this helplessness in bed. Having spent 9 months in the mother's womb, a human infant is born helpless and stays in the crib for another year under intensive postnatal care while its brain size continuously grows at the same rate as inside the womb, i.e. proportionally with its weight increase. The author surmises that this "secondary altriciality" was possible inside safe caves, thanks to intensive baby care by the extended family, particularly older females.

Wilson (2012) provides general scientific arguments based on his study on the eusocial origins and evolution of the hymenoptera, the insect taxonomic order that includes ants, bees, and aculeate (stinging) wasps. "Grouping by family can accelerate the spread of eusocial alleles, but it does not of itself lead to advanced social behavior. The causative agent of advanced social behavior is the advantage of a defensible nest, especially one expensive to make and within reach of a sustainable supply of food. ..... The second stage is the happenstance accumulation of other traits that make the change to eusociality still more likely. The most important is close care of the growing brood in the nest --- by feeding the young progressively, or cleaning the brood chambers, or guarding them, or some combination of the three." It is plausible that eusocial humans were first seen during the South African MSA thanks to defensible cave dwellings and close care of the child.

MSA already had (i) fire to cook, (ii) safe coastal caves as residence, (iii) secondary altriciality for a larger brain and (iv) eusociality to take care of babies. Apart from fire, these are not unique characteristics of modern humans and they all belong to similar background conditions when distinctive Neolithic industries emerged.

\subsection{Toba Volcanic Winter and the Acquisition of Phonemes}

In South African MSA (300 - $25 \mathrm{ka}), \mathrm{SB}$ and HP make up two outstanding Neolithic industries. The starting and ending ages for SB were estimated as 71.9 and $71.0 \mathrm{ka}$ and, for HP $64.8 \mathrm{ka}$ to $59.5 \mathrm{ka} \mathrm{(Jacob} \mathrm{2008).} \mathrm{SB} \mathrm{and} \mathrm{HP}$ emerged along the southern coastline of the African continent. The representative cave for SB is Blombos Cave, and those for HP are the Klasies River Mouth Caves.

The commencement of Still Bay [71.9 KA] coincides with the Toba volcanic winter. The Still Bay area is on a shallow beach. Klasies River Mouth Caves are located at a few hundred kilometers east of Still Bay, where the waves are high and strong enough to make extremely large caves at the mergence of the Atlantic and Indian Oceans. It is remarkable that the HP artefacts contain engraved ostrich eggshell containers. (Texier 2010) This sudden augmentation in the precision and sophistication of artefacts at $\mathrm{SB} / \mathrm{HP}$ indicates that there were critical technological breakthroughs at the beginning of SB/HP periods, one of which was probably language. Precisely 
this development of Neolithic industries in SB/HP corresponds with a two-stage development of logical properties in voice. By virtue of phonemes to generate an infinite number of word signs and moraic accents to make individual syllables distinguishable. Owing to accents, conceptual and grammatical syllables can be transmitted alternately without any mark, which enabled dualistic grammatical modulation of adjacent conceptual words.

In the past, it has been proposed that the so-called Toba event plunged the world into a volcanic winter, killing animal and plant life and squeezing our species to a few thousand individuals.

However, the author claims that the Toba eruption could not have been that devastating on the population because vaporized flood basalt from that era is much less than from previous eruptions: the volume of vaporized flood basalts at the Toba is $800 \mathrm{~km}^{3}$, while at one of big five extinctions, at the end of Permian 250MA, the volume of flood basalts was in excess of 1.5 million $\mathrm{km}^{3}, 2,000$ times bigger volume than the Toba eruption (Prothero 2004). It is not plausible that mass extinction should have taken place at the time of Toba volcanic winter.

How can this coincidence of the Toba volcanic winter with genetic statistical analysis and SB Neolithic industry be explained? The environmental stress of a volcanic winter, such as cold weather, less sunny days and less food, forced hunter-gatherers on the coastal zone of South Africa to spend more time than usual inside their caves, which functioned as sound shelters. They could sing loudly and as long as they liked without being recognized by enemies or predators. A South African natural scientist, Marais (1969) spent a couple of years with wild chacma baboons and reported that chacma baboons were singing together in the evening and night for several hours. So why not modern humans?

"And then from all sides would come the sound of mourning, a sound never uttered otherwise than on occasions of great sorrow - of death or parting...... In the case of the chacma the condition also disappears with the settling darkness. When the troop finally moved on to the krans or to the entrance of the sleeping-cave, the games were resumed and sometimes on moonlight nights continued for several hours." (Marais 1969)
It is probable that, through singing together, eusocial modern humans living inside caves autopoietically shared distinctive sound elements among community, which developed into phonemic click consonants.

\subsection{Use of Clicks Might Have Developed the Mandibular Bone}

Deagling (2012) found that "no consensus exists that there is a diagnostic anatomical indicator for articulate speech in human evolution" and made extensive analyses to get clearer images of the evolution of the unique mandible of modern human. He concluded that "high-frequency, low-magnitude loads associated with articulate speech are hypothesized to explain the apparent paradox of hypertrophied mandibular bone in contrast to the reduced bone thickness that typifies the remainder of the modern human skull."

It is plausible that the frequent use of the tongue to produce click sounds contributed to the unique mandible of modern humans and provided enough space under the oral floor to house the vocal tract with its descended larynx. Lieberman (2002) also suggested that "before the evolution of the modern human SVT (Supra-laryngeal Vocal Tract), the neural substrate that sequences the motor pattern generators that generate speech must have been in place". The production of clicks, followed by the syllable seems appropriate as a two-stage time series evolution.

"Clicks are known as consonants involving a velaric ingressive airstream mechanism, whose geographic and linguistic distribution is restricted to Khoisan and a small number of other languages in Africa" (Nakagawa 2007). Clicks are the phonemes which can be produced without airflow, i.e. before the laryngeal descent and vowels. "Existing analyses of clicks and non-clicks are seldom integrated into a single coherent phonological system..." (Traill 1997) This incoherency can be an evidence for evolution of the clicks-then-syllables time series. Once syllables are obtained, only the Khoisan kept clicks as they were surrounded by the world named by click based concepts, while those who left Southern Africa abandoned clicks as they had enough phonemes with syllables. 


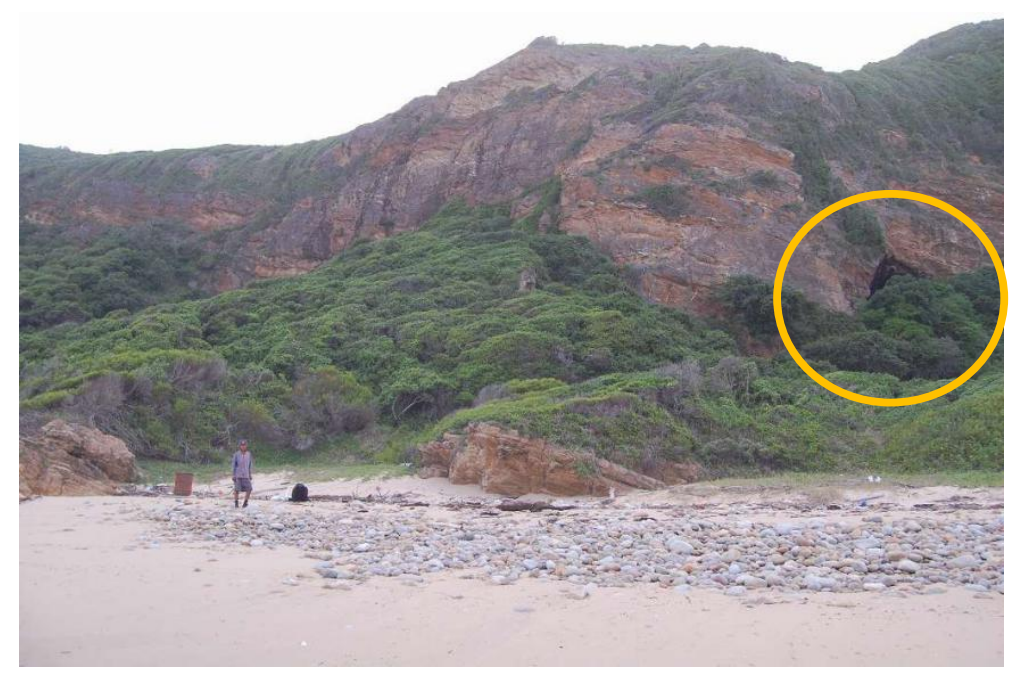

Figure 15. Klasies River Mouth Cave No.3 Entrance

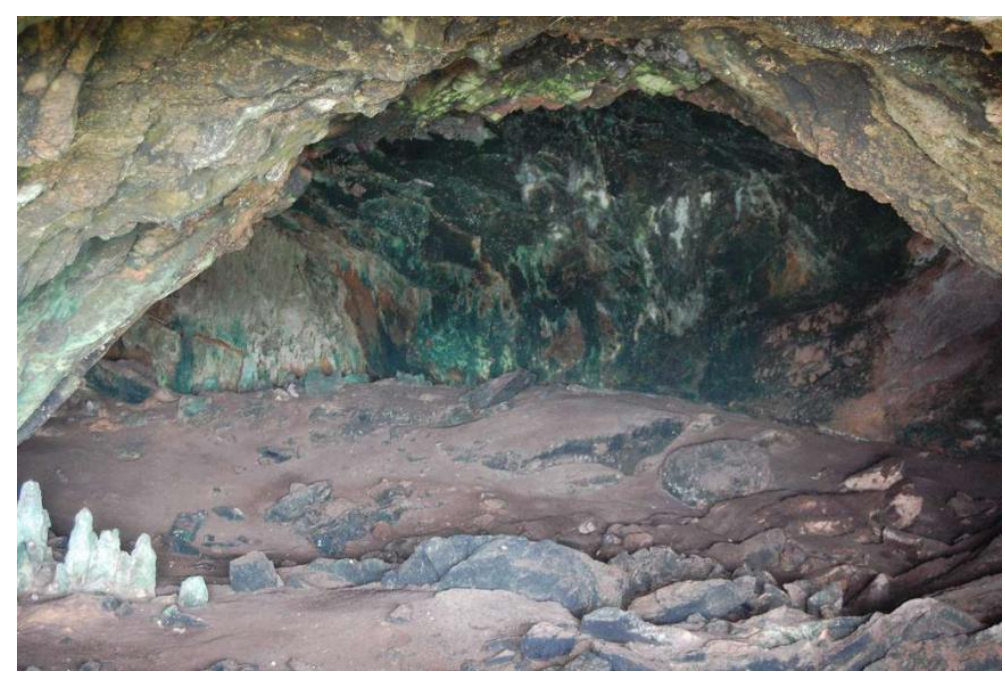

Figure 16. Klasies River Mouth Cave No.3 Looking inside from the entrance

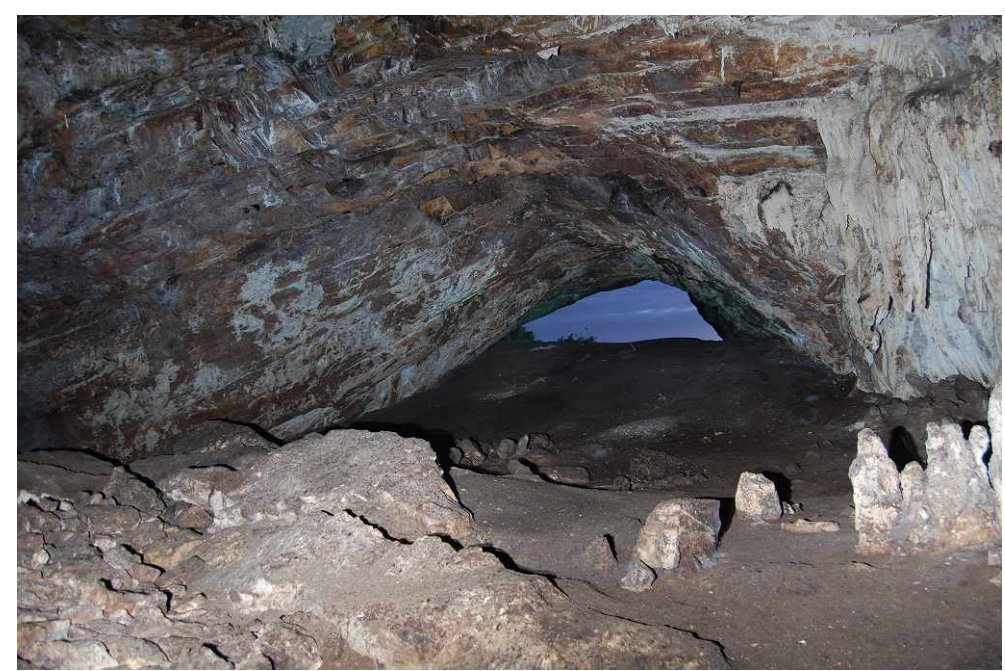

Figure 17. Klasies River Mouth Cave No.3 Looking outward (West) from the inside 


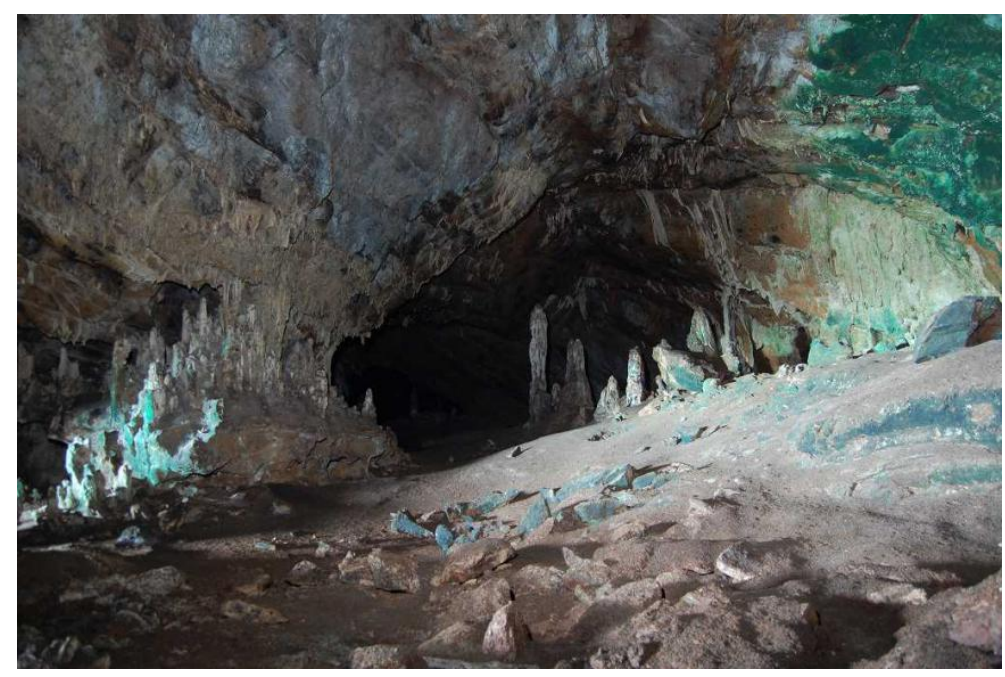

Figure 18. Klasies River Mouth Cave No.3 Looking at the inside corridor

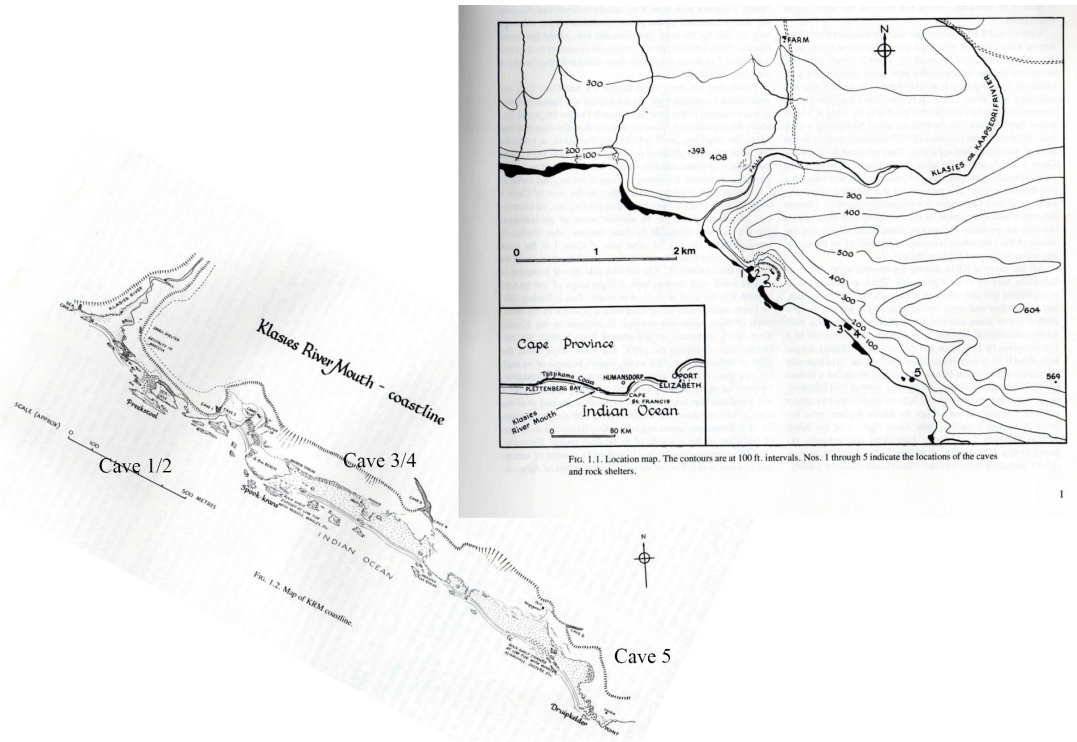

Figure 19. Map of Klasies River Mouth Caves 1-5 (Singer Wymer 1982)

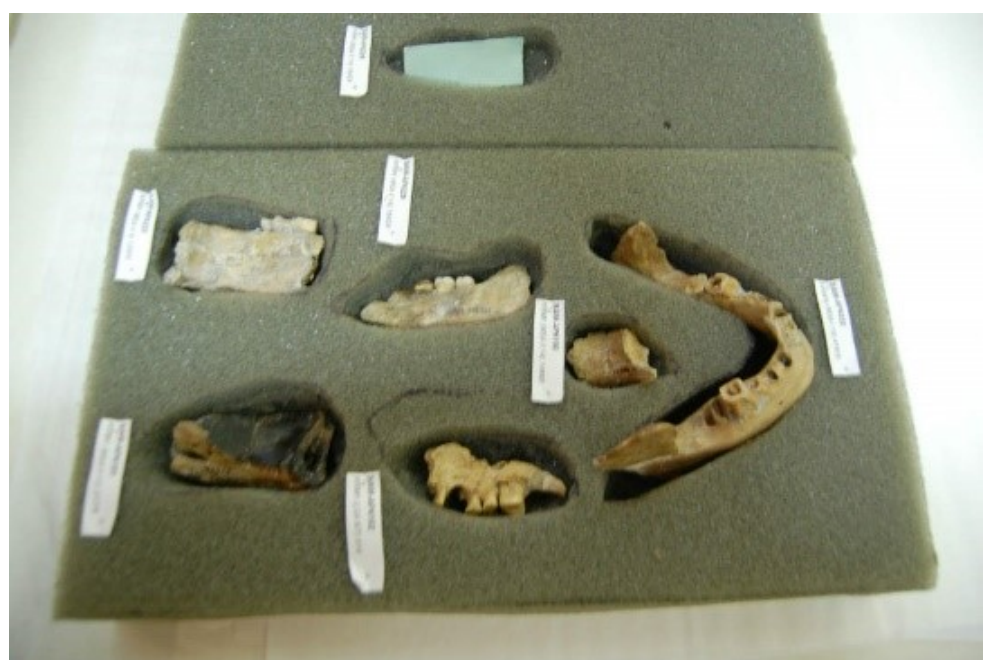

Figure 20. Mandible unearthed at KRM Cave No.1 collected at IZIKO South Africa Museum Slave Lodge 


\section{Conclusions}

Amongst the artefacts unearthed from Howiesons Poort, there were types of tools which were only known from 'advanced' Upper rather than Middle Palaeolithic sites in Europe, and the stratigraphic position (66-58 KA) of Howiesons Poort was highlighted by the excavation of the Klasies River Mouth main site (Wurz 1999). This time-reversal has not been fully discussed and analyzed, as it requires a Copernican turn from Eurocentric perspective. It has hardly been imagined that the two distinctive Neolithic cultures of Still Bay (72-71 KA) and Howiesons Poort (66-58 KA) could correspond to the two stage acquisition of logical properties in speech sound, namely phonemes by click consonants, then morae by vowel accented syllables. In DL, the linguistic humans are supposed to be born with ability to produce syllables.

The South African Origin of Linguistic Human Hypothesis is comprehensive and plausible. It is complementary to the results of statistical genetic analyses as well as to the geophysical ice core analysis which estimated ancient climatic conditions such as the Toba Volcanic Winter. Click to syllable time series evolution corresponds well with SB to HP Neolithic technological breakthroughs. This had not been hypothesized because of the lack of knowledge on the outstanding variations of SB (72-71KA) and HP (66-58 KA) in South African MSA $(300-25 \mathrm{KA})$, and the lack of knowledge on the importance of logical properties in speech sound, phonemes and accents. Eurocentric prejudice also seems to have prevented many scholars from accepting an African Origin Hypotheses of modern linguistic humans.

From the point of view of vertebrate CNS mechanism, sign reflex can cope with tens of millions of different signs. Not only linguistic humans but also any vertebrate can recognize as many signs and corresponding meanings as presented. The only limitation is in the ability to vocalize the same. If we can establish an efficient education system and method of expression for non-human animals, we may be able to communicate with most non-human animals using linguistic concepts.

It is necessary to understand the origin of language and brain mechanism for linguistic processing because we are at the third and final evolution of human digital language with interactive keyword search and electric transfer of linguistic information using computer networks.

\section{Acknowledgements}

I am grateful to the West African Linguistic Society who provided me with theopportunity to deliver a keynote speech at the $30^{\text {th }}$ WALC held in August 2017 at Winneba, Ghana, and I am also grateful to those West African linguists who kindly attended and seemed to appreciate my lecture. While this full paper version was reviewed but not published in the WALC-30 Proceedings, I hope to continue to work closely with not only Western but also Pan African linguists, paying full respect to the philosophy of Kwame Nkrumah. I am grateful to the editors at Horizon Research Publishing Corporation who publishes this article in Linguistics and Literature Studies.

\section{REFERENCES}

[1] Cann R.L., Stoneking M. \& Wilson A.C.(1987) Mitochondrial DNA and Human Evolution, Nature, 325, 31-6.

[2] Chiba,T. (1935) Research Into the Nature \& Scope of Accent in the Light of Experimental Phonetics, Fuzanbo, Tokyo

[3] Chiba, T. and Kajiyama M. (1942) The Vowel: Its Nature and. Structure, Tokyo-Kaiseikan, Tokyo (Japanese translation : Iwanami Shoten, Tokyo, 2003)

[4] Chomsky, N. (1964) Current issues in linguistic theory, Mouton: The Hague

[5] Chomsky, N. (1988) Language and problems of knowledge The Managua Lectures

[6] Deagling, D.J.(2012) The Human Mandible and the Origins of Speech, J. of Anthropology

[7] Goodwin, A.J.H. \& Van Riet Lowe, C. (1929) The Stone Age cultures of South Africa. Annals of the South African Museum 27.

[8] Henn B.M. et al. (2011) Hunter-gatherer genomic diversity suggests a southern African origin for modern humans PNAS 108:5154-5162

[9] Jacobs, Z. et al. (2008) Ages for the Middle Stone Age of Southern Africa: Implications for Human Behavior and Dispersal, Science 322: 733-735

[10] Jerne, N.K. (1974) Toward a Network Theory of Immune System, Ann Immunol (Paris). 125C(1-2) :373-89

[11] Jerne, N.K. (1984) The Generative Grammar of the Immune System (The Nobel Lecture)

[12] Lancaster F.W. (1995) The Academic Boycott of South Africa: Symbolic Gesture or Effective Agent of Change? Perspectives, 15:1 (Fall 1995)

[13] Lombard, M., Wadley, L., Deacon, J., Wurz, S., Parsons, I., Mohapi, M., Swart, J. \& Mitchell, P. (2012). South African and Lesotho Stone Age sequence updated (I). South African Archaeological Bulletin 67(195):120-144.

[14] Maekawa K., (2002) From articulatory phonetics to the physics of speech: Contribution of Chiba and Kajiyama, Acoust.Sci. \& Tech. 23(4):185-188

[15] Marais, E., (1969) The Soul of the Ape, Stephan Phillips, Africana Series

[16] Martin RD (1990) Primate origins and evolution: a phylogenetic reconstruction Princeton Univ.

[17] Minty (2017) Abdul Minty Voice File, The Commonwealth Oral Histories, Inst. of Commonwealth Studies, Univ. of 


\section{London}

[18] Nakagawa, H. (2007) Integration of the clicks and the non-clicks Area and culture studies / Tokyo Univ. of Foreign Studies 75:87-96

[19] Noll, H. (2003) The Digital Origin of Human Language - a Synthesis, BioEssays 25:489-500Peart-Binns J.S. (1973) Chapter 14 Sharpeville - A consequence of Pass Laws, in "Ambrose Reeves" pp206-215, Victor Gollancz Ltd, London

[20] Pepper W.J., Braude S.H., Lacey E.A., Sherman P.W. "Vocalization of the Naked Mole-Rat" in Alexander RD et al. (1991) The Biology of the Naked Mole-Rat, Princeton Univ.

[21] Phillips, D.P. (2001) Introduction to the Central Auditory Nervous System, in "Physiology of the Ear" 2nd Edition, San Diego : Singular

[22] Portmann A. (1944) Biologische Fragmente zu einer Lehre vom Menschen Basel: Benno Schwabe \& Co. Verlag; (Jap. Tr., Tokyo, Iwanami 1961)

[23] Prothero D.R., (2004), Bringing FOSSILS to Life - An Introduction to Paleobiology (2nd Ed.) McGrawHill Higher Education

[24] Reeves A., (1960) Shooting at Sharpeville - the Agony of South Africa, London Victor Gollancz Ltd

[25] Royer D.F., Lockwood C.A., Scott J.E., Grine F.E., (2009) Size Variation in Early Human Mandibles and Molars from Klasies River, South Africa: Comparison with Other Middle and Late Pleistocene Assemblages and with Modern Humans, AM. J. PHYSICAL ANTHROPOLOGY $140: 312-323$

[26] Singer, R. \& Wymer, J. (1982) The Middle Stone Age at Klasies River Mouth in South Africa Chicago U.P.

[27] Smith, J.M., Szathmary, E. (1999) The origins of Life, Oxford Univ. Press

[28] Taylor, F.B., (1910) Bearing of the Tertiary mountain belt on the origin of the earth's plan, Bulletin of the Geological Society of America, 21:179-226

[29] Texier, P-J et al. (2010), A Howiesons Poort tradition of engraving ostrich eggshell containers dated to 60,000 years ago at Diepkloof Rock Shelter, South Africa PNAS 107 (14) 6180-6185

[30] Tokumaru, K. (2018) A Mobile Hypothesis of Neural Networks for Spinal Reflex and Linguistic Processing (Digital Linguistics), Linguistics and Literature Studies 6(6) 267-277

[31] Tokumaru, K. (2019) An Information Theory of Language (Digital Linguistics), Linguistics and Literature Studies 7(5) 206-219

[32] Traill, A. (1997) Linguistic phonetic features for clicks. In R.K. Herbert (ed), African linguistics at the crossroads: papers from Kwaluseni (1st World Congress of African Linguistics, Swaziland, 18-22, July, 1994), pp.99-117

[33] Ucko, P. (1987) Academic Freedom \& Apartheid, the story of the World Archaeological Congress. Duckworth, London
[34] Vygotsky, L (1934) Thought and Language. Cambridge, MA. MIT Press 1986, (Jap. tr. by Shibata Y. Tokyo, Meiji Shoin 1956)

[35] Welch A.W. (2005) An Ordinary Atrocity: Sharpeville and Its Massacre/The Assassin: A Story of Race and Rage in the Land of Apartheid, African Studies Review 48:174-176

[36] Westphal, E.O.J. (1971) The click languages of Southern and Eastern Africa, in Sebeok, T.A., Current trends in Linguistics, Vol. 7: Berlin: Mouton

[37] Wilson E.O., (2012) The Social Conquest of Earth, Liveright, New York

[38] Wurz S., (1999) The Hoawiesons Poort Backed Artefacts from Klasies River: An Argument for Symbolic Behaviour, S.A.A.B. $54: 38-50$ 